\title{
An analysis of the relationship between bulk tank milk quality and wash water quality on dairy farms in Ontario, Canada
}

\author{
N. R. Perkins, ${ }^{1}{ }^{1}$ D. F. Kelton, ${ }^{*}$ K. J. Hand,† G. MacNaughton, $\ddagger$ O. Berke, ${ }^{*}$ and K. E. Leslie ${ }^{*}$ \\ *Department of Population Medicine, University of Guelph, Guelph, Ontario, Canada, N1G 2W1 \\ †CanWest Dairy Herd Improvement, Guelph, Ontario, Canada, N1K 1E5 \\ ‡Dairy Farmers of Ontario, Mississauga, Ontario, Canada, L5N 2L8
}

\section{ABSTRACT}

The objective of this study was to identify regions at high risk for bacterial water or milk contamination, as well as risk factors associated with high bacteria counts in raw milk in Ontario, Canada. Between 2003 and 2004, the Dairy Farmers of Ontario (DFO) tested water samples from 5,421 farms in Ontario for the presence of Escherichia coli and coliforms. The water samples were collected as "point-of-use" samples, meaning that each sample was taken from a tap or water hose in the milk house as soon as the water was turned on. Routine, monthly raw milk bacterial counts were determined by DFO using BactoScan (Foss, Hillerød, Denmark). BactoScan data were retrieved from DFO for all of the farms with water test results. The prevalence of samples with E. coli and coliforms in water and elevated bacteria counts in raw milk was 13.6, 53.8, and $2.8 \%$, respectively. The spatial analysis, using a scan statistic, revealed 1 coliform and $3 \mathrm{E}$. coli clusters of contaminated water, but no clusters of elevated milk bacteria counts in raw milk in southern Ontario. The coliform water contamination cluster was the largest, with a radius of approximately $200 \mathrm{~km}$. Regression analysis indicated that risk factors associated with the occurrence of high levels of bacteria in raw milk were elevated average monthly somatic cell count, increased total milk production, cooler seasons of the year, and the presence of $E$. coli in wash water.

Key words: wash water quality, spatial epidemiology, raw milk quality

\section{INTRODUCTION}

Various aspects of dairy herd management influence the bacteriological quality of raw milk. Milk that is synthesized and secreted in the udder is sterile. How-

Received January 13, 2009.

Accepted April 16, 2009.

${ }^{1}$ Corresponding author: perkinsn@uoguelph.ca ever, bacterial contamination of raw milk can occur in the gland, during milking, in storage, during transport, or processing (Holm et al., 2004). The most consistent sources of bacterial contamination of raw milk are improperly cleaned milking and cooling equipment surfaces. Seemingly clean equipment can accumulate very high numbers of bacteria on their surfaces in the time between milkings. When the cleaning and disinfection process is inadequate, a build-up of potentially pathogenic bacteria occurs. Inadequate surface disinfection can also occur as a result of using contaminated water for washing (Saran, 1995).

There are 2 main types of milking equipment cleaning methods, manual and circulation. Manual cleaning is primarily used for bucket milking machines and ancillary equipment or on very small dairy operations (Saran, 1995). Circulation cleaning is commonly used in moderate to large-scale dairies, especially those with milking parlors. Circulation cleaning is a form of cleaning-in-place (CIP). The CIP process can be very effective at removing bacteria that aggregate on milk contact surfaces. Several factors determine the degree of effectiveness of CIP systems, such as cleaning surface characteristics, cleaning time, cleaning agent, and the quality of the water source.

Many factors on dairy farms can contribute to bacteria counts in the raw milk. These factors include cow health, milk cooling and storage protocols, personnel training, cleaning regimens, and so on. Dairy farms are very dynamic production systems that rely on many operations and processes on-farm to be working properly to produce raw milk of high quality. Problems tend to occur when one of these processes is malfunctioning. As a result, there would be an increased risk of bacterial contamination of the raw milk. A major source of bacteria in raw milk is the water used to clean the milking and storage equipment (Jayarao and Wang, 1999).

The Canadian Quality Milk program has set criteria for water quality on dairy farms. Initial testing has suggested that as many as half of Ontario dairy farms do not meet these water quality standards (Dairy Farmers of Ontario, 2006). Test results suggest that al- 
though some water may be contaminated at its origin, significant contamination occurs in the plumbing and is expressed as an elevation in bacteria counts at the point of use. In Ontario, water used to wash milking surfaces should contain no coliforms and no Escherichia coli (Dairy Farmers of Ontario, 2004). The presence of coliforms generally suggests contamination by surface water. Coliforms are commonly present in sewage and animal fecal matter, but are also found on vegetation and in soil. These bacteria are used as indicators of disease-causing organisms in water (Dairy Farmers of Ontario, 2004). The presence of E. coli in water samples indicates that fecal contamination has occurred. There are many different strains of these bacteria, with most strains being harmless and part of the normal flora of the intestine. There are a few strains that can cause severe disease or even death.

Studies have investigated the prevalence of $E$. coli and coliforms in farmstead domestic well water in Ontario, and found that approximately 15 and $40 \%$ of wells, respectively, are contaminated (Goss et al., 1998). Another study looking at the reported cases of human illness caused by E. coli found that Ontario represented nearly half of the reported cases in Canada (Michel et al., 1999). Therefore, it is important to use geographical analyses to identify subregions of Ontario with an increased risk of contaminated water to effectively implement veterinary public health control measures.

The first objective of this research project was to quantify the quality of raw milk and (wash) water on Ontario dairy farms. Second, the study aimed to identify geographical areas that are at a high risk for bacterial contamination of wash water in Ontario. Finally, factors associated with, and risk factors for, the occurrence of high bacteria counts in raw milk were investigated.

\section{MATERIALS AND METHODS}

\section{Farm Selection and Testing}

The Dairy Farmers of Ontario (DFO) performed 2 rounds of cross-sectional sampling to investigate water quality on dairy farms in Ontario. Using statistical analyses to identify differences in the prevalence of $E$. coli and coliform contamination between samplings (data not shown), it was determined that there was no meaningful difference with respect to the prevalence of E. coli and coliforms between samples 1 and 2. In addition, approximately 1,000 farms did not have a second water sample collected. For the purposes of this study, only the first round of sampling was utilized for the spatial analysis. Both rounds of water testing were performed between 2003 and 2004 on 5,421 dairy farms in Ontario, Canada. The water samples were collected as point-of-use samples, meaning that each sample was taken from a tap or water hose in the milk house as soon as the water was turned on. Point-of-use sampling was used to simulate the regular usage patterns on the farm. Based on this method, the source of contamination could be the well, the plumbing system, or the tap or hose where the sample was collected. A minimum of $100 \mathrm{~mL}$ of water was collected for testing of E. coli and coliforms in the sample. The testing was done using the EPA Method 1604 membrane filtration method, using a simultaneous detection technique (MI medium, \#214986, Becton Dickinson, Madison, WI) to identify total coliforms and E. coli in water (United States Environmental Protection Agency, 2002). In brief, the water sample was filtered through a cellulose ester membrane filter to extract the bacteria from the sample. The filter was placed on MI agar, a membrane filter agar medium to detect total coliforms and E. coli simultaneously, and incubated at $35^{\circ} \mathrm{C}$ for $24 \mathrm{~h}$. The plates were inspected for growth of total coliforms, specifically E. coli. To meet DFO regulations, a water sample should not contain E. coli and should have a coliform count of zero. A case farm was defined as any farm with a $100-\mathrm{mL}$ water sample with growth of $E$. coli or a coliform count $>0$. All other farms were included as control farms.

Milk samples from Ontario dairy farms undergo weekly SCC testing, using the Series 400 Fossomatic (Hillerød, Denmark), and monthly milk bacteria testing, using flow cytometry on the Foss BactoScan (FC Type $73700,100 \mathrm{H})$ at Laboratory Services of the University of Guelph (Guelph, Ontario, Canada). The BactoScan measures the individual bacteria counts (ibc) in raw milk and results are reported as ibc per milliliter. The DFO uses a cut-point of $121,000 \mathrm{ibc} / \mathrm{mL}$ to signify the need for further milk quality testing. If this cut-point, or even higher levels, are attained in 2 of 3 consecutive BactoScan test results, a penalty to the farm occurs. The occurrence of 4 BactoScan penalties in a 12-mo period results in the herd being shut off from the market. The BactoScan and average monthly SCC data were retrieved from DFO for all of the farms with water quality sample results. Average monthly SCC is the average value of the 4 weekly SCC tests completed in the month of water sampling. The total milk shipped from each producer during the month of water testing was also obtained. For spatial analysis, milk bacteria counts were categorized into positive and negative farms. A milk bacteria-positive farm was a farm with $>121,000$ $\mathrm{ibc} / \mathrm{mL}$ in the raw milk sample performed in the same month as the water quality sample. A milk bacterianegative farm had $\leq 121,000 \mathrm{ibc} / \mathrm{mL}$. 


\section{Sample Determination}

Because of the sparsity of observations in northern Ontario and large differences in geographical and demographic characteristics, the spatial analysis was restricted to farms in southern Ontario. The north (y) and east $(\mathrm{x})$ coordinates of each farm were established in degrees of latitude and longitude, respectively, and any farm without location or geographical information was removed from the data set for spatial analysis. Any water test results that did not have corresponding milk quality data $(\mathrm{n}=56)$ were removed from the regression analysis.

\section{Data Handling/Software}

The data sets from DFO were received in Microsoft Excel spreadsheet form. For spatial analysis, the data were converted into a text file and read into R 2.2.1 (R Foundation for Statistical Computing, Vienna, Austria; http://www.R-project.org). Geographical cluster analysis was performed in ClusterSeer 2 (TerraSeer, Crystal Lake, IL) and SaTScan 5.1.1 (SatScan, Boston, MA; Kuldorff, 2006). Regression analysis was completed using SAS 9.1 (SAS Institute Inc., Cary, MA).

\section{Data Analyses}

Spatial Analysis. Separate maps for E. coli in water, coliforms in water, and bacteria counts in milk were created to explore the geographical distribution of farm locations in southern Ontario, as well as the distributions of the case farms.

To evaluate the risk of bacteria in both water and milk, risk maps were generated to identify the risk distribution using kernel density estimation (Berke, 2005). The risk of bacterial contamination was indicated by the ratio of case farms over the entire population of farms at risk. The bandwidth used for kernel estimation is a scaling parameter controlling the smoothness of the intensity functions for the case and at-risk farm populations. The larger the bandwidth, the smoother the surface map. The optimum bandwidth parameter for each analysis was determined through trial and error. The risk ratios for E. coli, coliform, and milk bacteria counts were plotted as risk maps for southern Ontario, and contour lines identify specific risk levels on the maps.

Global clustering in the data was evaluated using the Cuzick and Edwards' test (Cuzick and Edwards, 1990). This test is based on functions of the distances between case locations and the observed nearest (k) "neighbor" case locations presented as test statistics. The default of 10 nearest-neighbor calculations was used for each of $E$. coli, coliform, and milk bacteria count data sets. Monte Carlo simulations were run to estimate the $P$-value.

Specific spatial clusters in the data were identified using the spatial scan statistic (Kulldorff and Nagarwalla, 1995). The spatial scan statistic uses circles (of different sizes, including up to $50 \%$ of the population) placed at every junction of a grid, based on the latitude and longitude coordinates on the map, and calculates the number of observed and expected cases within and surrounding the circle. A likelihood ratio is determined for the circle with the highest likelihood to be possible clusters. Along with the likelihood ratio, a $P$-value is calculated, based on Monte Carlo simulations, to determine the significance of the cluster (Aamodt et al., 2006). The scan statistic has good power in detecting spatial or geographical clusters (Song and Kulldorff, 2003). The spatial scan test was applied under the assumptions of the Bernoulli model. The scanning window was set at a maximum cluster size of 50\%, and 999 replications were run to calculate Monte Carlo $P$-values.

A circle was placed on the corresponding risk maps to identify the cluster location and size, as identified by the scan test. Only significant clusters were included in the risk maps. The relative risk of $E$. coli and coliforms in water was calculated using the ratio of the background risk [estimated from cases and population-atrisk outside the identified cluster(s)] and the risk at any location of interest. Further, relative risk maps were created with contour lines identifying different levels of relative risk (Berke, 2005).

Regression Analysis. Multivariable linear regression was used to model the relationship of milk bacteria counts in raw milk to possible risk factors for contaminated milk. A total of 9,771 observations were used for analysis. Milk bacteria counts remained a continuous variable with only the very high values truncated. Any milk bacteria result $>300,000 \mathrm{ibc} / \mathrm{mL}$ was put into a single category of " $300,000 \mathrm{ibc} / \mathrm{mL}$." The milk bacteria results $\leq 300,000 \mathrm{ibc} / \mathrm{mL}$ represented $99 \%$ of the data. A log-transformation was used to generate appropriate Gaussian distributed data of milk bacteria counts. The independent variables introduced into the model were the presence of $E$. coli in water, coliforms in water, monthly total kilograms of milk shipped by each herd, cool (October-April) or warm month of the year (May-September), and monthly SCC average. The monthly SCC average is reported as thousands of cells per milliliter. Interaction among all explanatory variables was investigated and only significant $(P<0.05)$ interaction terms were included in the final model. The insignificant covariates $(P>0.05)$ were removed from the model in a backward elimination process. Residuals were examined to ensure a good fit. 
Table 1. Prevalence of Escherichia coli-positive and coliform-positive wash water and bulk tank samples with a high bacteria count in southern Ontario dairy farms at 2 samplings

\begin{tabular}{lccc}
\hline Sample & E. $\operatorname{coli}^{1}(\%)$ & Coliform $^{2}(\%)$ & $\begin{array}{c}\text { High milk bacteria } \\
\text { count }^{3}(\%)\end{array}$ \\
\hline First wash water sample $(\mathrm{n}=5,218)$ & 13.5 & 53.7 & 2.8 \\
Second wash water sample $(\mathrm{n}=4,377)$ & 12.0 & 58.2 & 3.0 \\
\hline
\end{tabular}

${ }^{1}$ An E. coli case consists of any water sample with $>0$ E. coli.

${ }^{2} \mathrm{~A}$ coliform case consists of any water sample with $>0$ coliforms.

${ }^{3}$ High milk bacteria counts consist of any milk sample with $>121,000 \mathrm{ibc} / \mathrm{mL}$, where ibc $=$ individual bacterial count.

\section{RESULTS}

\section{Spatial Analysis}

The DFO collected water samples from over 5,000 herds in Ontario in 2003-2004, and most herds were sampled twice. The prevalence of E. coli-positive, coliform-positive, and high milk bacteria count farms from the first and second rounds of water testing are shown in Table 1. Water used for washing the bulk tank was E. coli- and coliform-positive in $>10$ and $>50 \%$ of the farms, respectively, and these results were very similar between the 2 rounds of testing. Therefore, spatial analysis was restricted to the first water sample. A total of 5,218 farms were included in the spatial analysis (15 farms missing locational information and 188 farms that were outside the boundary of southern Ontario were removed from the data set). Figure 1 depicts the spatial distribution of study farms. The prevalence of

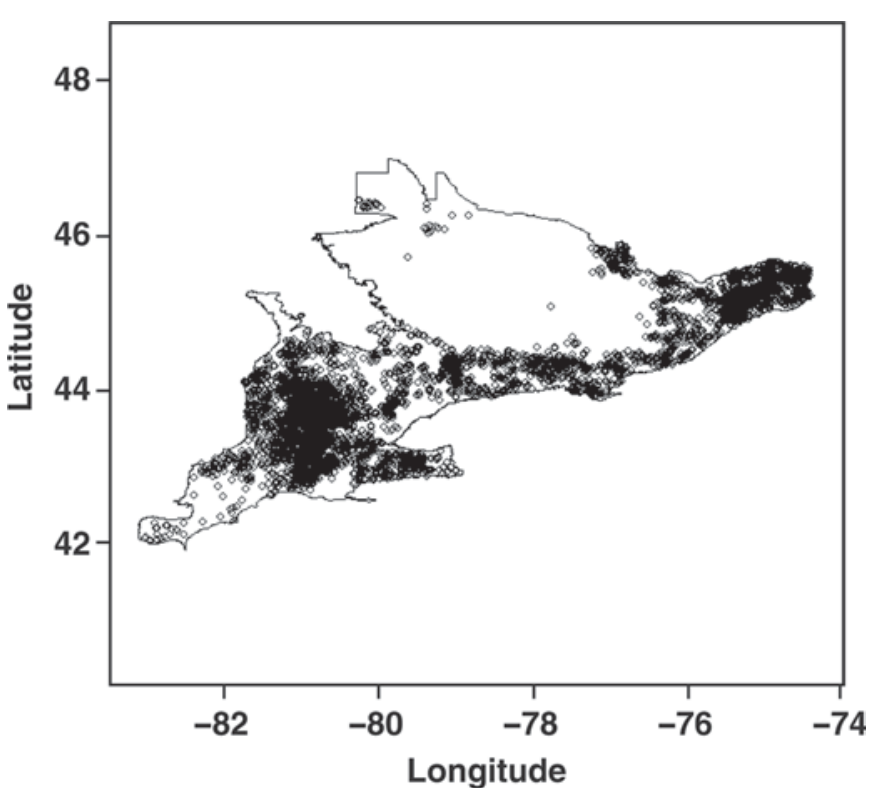

Figure 1. Spatial distribution of study farms in southern Ontario, Canada, depicted using degrees $(\mathrm{N})$ latitude and degrees $(\mathrm{W})$ longitude.
E. coli, coliform, and high milk bacteria count results before and after the northern Ontario farms were removed differed only by $0.1 \%$. In the farms in southern Ontario, the percentage contamination of milk or water was $13.6,53.8$, and $2.8 \%$ for E. coli, coliform, and milk bacteria counts, respectively.

There was significant clustering in the E. coli and coliform data at the $99 \%$ confidence level $(P<0.01)$. There was no clustering identified in the milk bacteria count data.

The risk map identified a larger risk ratio of $E$. coli contamination in the area between $76^{\circ} \mathrm{W}$ and $79^{\circ} \mathrm{W}$, as identified by contour lines in Figure 2. This area of the province had a prevalence of $E$. coli between 15 and $25 \%$. Similarly, the risk map of coliform contamination found elevated risk in the area between $77^{\circ} \mathrm{W}$ and $79^{\circ} \mathrm{W}$, with prevalence between 60 and $70 \%$ (Figure 3 ). Alternatively, for farms with high milk bacteria counts, the risk was consistently low across southern Ontario (i.e., no trend/cluster) with prevalence ranging from 1.5 to $3.0 \%$.

There were several significant clusters of contaminated water samples, as identified by the scan statistic (Table 2). The E. coli clusters comprised 594 (cluster A), 261 (cluster B), and 53 (cluster C) farms, of which 193, 107, and 34 were case farms, respectively. The 3 significant E. coli clusters had radii of $110 \mathrm{~km}$ (cluster A), $95 \mathrm{~km}$ (cluster B), and $25 \mathrm{~km}$ (cluster C) (Figure 2). The coliform cluster comprised 2,132 farms, of which 1,414 were case farms. The coliform cluster was the largest cluster in the data and had a radius of 195 $\mathrm{km}$, located in the central portion of southern Ontario (Figure 3).

The relative risk maps for E. coli (Figure 4) and coliform (Figure 5) water contamination depicted an increased relative risk between $76^{\circ} \mathrm{W}$ and $79^{\circ} \mathrm{W}$. The producers in this area were 2.5 to 3.0 times more likely to have E. coli-contaminated water than the producers that operated outside of this area. Similarly, the producers in this region were 1.25 to 1.5 times more likely to have coliforms in their water than farms outside this region. 


\section{Regression Analysis}

The water test results from the point-of-use wash water samples on Ontario dairy farms and the milk quality test results from the same period were used in a linear regression analysis. Log-milk bacteria count was the dependent variable, and season, monthly SCC average, $E$. coli presence in wash water, coliform presence in wash water, and total milk production were the independent variables. In total, 9,771 water samples (sample 1 and 2 together) with corresponding raw milk quality results were included in the analysis. The presence of coliforms in water was treated as a covariate; however, it did not significantly influence the linear regression model. Several factors were significantly associated with milk bacteria counts in raw bulk tank milk (Table 3). The presence of $E$. coli in wash water samples was significantly associated with elevated bacteria counts in raw milk samples. However, E. coli in wash water increased milk bacteria counts by only one unit. Monthly SCC average contributed to milk bacteria counts in the regression model. Yet, the effect of monthly SCC average on milk bacteria counts varied by season and by total milk shipped. In the cooler months, increasing monthly SCC average was associated with higher milk bacteria counts when compared with the warmer months. The difference in milk bacteria counts between the seasons was larger as the monthly SCC average increased. At low levels of monthly SCC averages $(<300,000$ cells/ $\mathrm{mL}$ ) and with increasing total milk production, the effect of season on milk bacteria counts was minimal, but the bacteria counts decreased slightly. Alternatively, at higher levels of monthly SCC average $(>300,000$ cells $/ \mathrm{mL}$ ) and increasing total milk production, the increase in milk bacteria counts by season was more pronounced. All variables except the interaction term for SCC average and season $(P<0.02)$ were significant in the linear model at the $99 \%$ level. Analysis of the residuals indicated a good model fit.

\section{DISCUSSION}

The spatial and regression analyses identified geographical areas with increased prevalence of bacteria in the water used to wash milking equipment and risk factors associated with increased levels of bacteria in raw milk samples.

The water quality on Ontario dairy farms has not been studied in depth recently, making it difficult to determine if the prevalence of $E$. coli and coliforms in this study is an adequate representation of water contamination in Ontario. In Brazil, coliforms were found in $60 \%$ of samples of water used to wash milking equipment, which is in line with the prevalence in the current

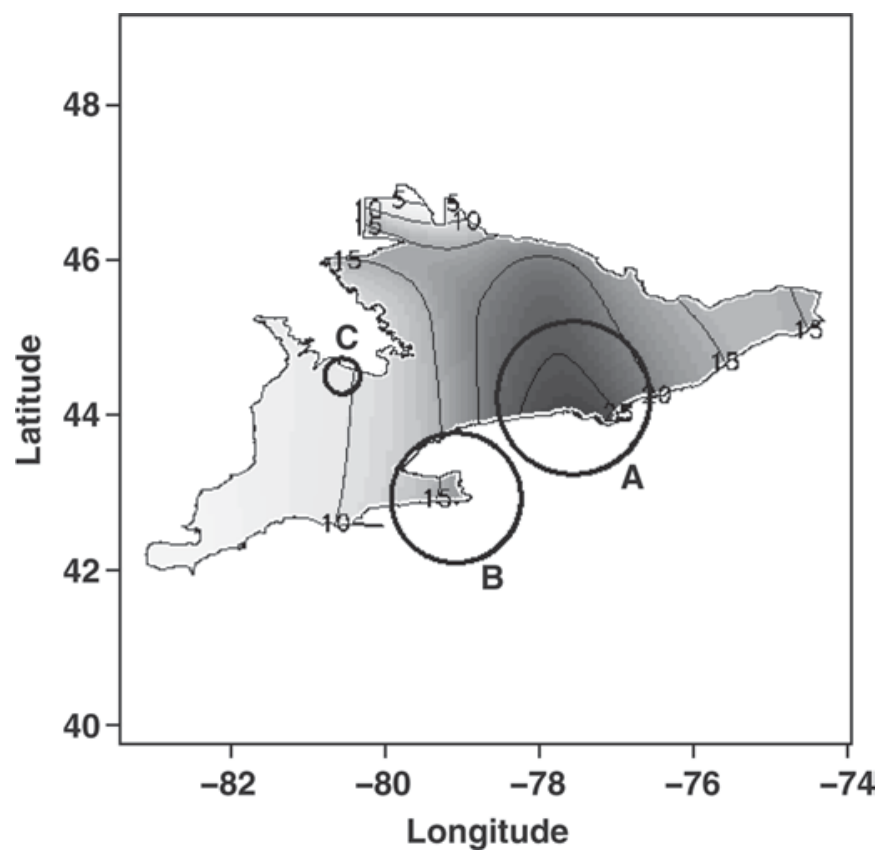

Figure 2. A risk map of Escherichia coli-contaminated water on dairy farms in southern Ontario, Canada, depicted using degrees (N) latitude and degrees (W) longitude with contour lines to identify the risk levels of water contamination. Significant clusters of water contamination identified by circles (A, B, and C) had radii of $110 \mathrm{~km}$ (cluster A), $95 \mathrm{~km}$ (cluster B), and $25 \mathrm{~km}$ (cluster C), respectively, as identified using the scan statistic. The $E$. coli clusters comprised 594 (cluster A), 261 (cluster B), and 53 (cluster C) farms, of which 193, 107 , and 34 were case farms, respectively.

study (Lopes and Stamford, 1997). A large portion of all farms in Ontario use well water as the main water source for the dairy operation. Previous research projects have reported a prevalence of $15 \%$ for E. coli and a range of 34 to $44 \%$ for total coliform contamination in well water in Ontario (Goss et al., 1998). Goss et al. (1998) found that nearly $40 \%$ of the rural domestic wells tested (in either season) in Ontario did not meet provincial requirements for drinking water of zero $E$. coli and $\leq 5$ coliforms per $100 \mathrm{~mL}$. These previously reported estimates agree with the prevalence of wash water contamination in the current study.

It is important to mention the differences between point-of-use sampling performed in the current study and well water sampling used in most other research projects. Point-of-use sampling is unique because the water sample directly relates to the condition of the water when consumed or used on the farm because it is taken from the same source and in the same way that the water is utilized. To simulate common usage practices, the sample was taken from a commonly used tap or hose as soon as the water was turned on. This type of sampling does not provide any information regarding the exact source of the water contamination. The water 
Table 2. The locations of the significant clusters of Escherichia coli-positive, coliform-positive, and farms with elevated bulk tank milk bacteria counts identified using the scan statistic in SaTScan ${ }^{1}$

\begin{tabular}{|c|c|c|c|c|c|}
\hline \multicolumn{2}{|l|}{ Item } & \multirow{2}{*}{$\frac{P \text {-value }}{0.001}$} & \multirow{2}{*}{$\frac{\text { Radius }(\mathrm{km})}{110}$} & \multirow{2}{*}{$\frac{\text { Latitude }}{44^{\circ} \mathrm{N}}$} & \multirow{2}{*}{$\frac{\text { Longitude }}{77^{\circ} \mathrm{W}}$} \\
\hline E. coli & A & & & & \\
\hline & B & 0.001 & 95 & $42^{\circ} \mathrm{N}$ & $79^{\circ} \mathrm{W}$ \\
\hline & $\mathrm{C}$ & 0.033 & 25 & $44^{\circ} \mathrm{N}$ & $80^{\circ} \mathrm{W}$ \\
\hline \multirow{2}{*}{\multicolumn{2}{|c|}{$\begin{array}{l}\text { Coliform } \\
\text { Milk bacteria count }\end{array}$}} & 0.001 & 195 & $44^{\circ} \mathrm{N}$ & $78^{\circ} \mathrm{W}$ \\
\hline & & \multicolumn{4}{|c|}{ No significant clusters identified } \\
\hline
\end{tabular}

${ }^{1}$ SatScan, Boston, MA.

contamination could be from the source (well or surface water), somewhere in the pipelines, in the filtration system, or at the tap or hose end (Unc, 2004). Source water sampling involves taking a water sample from a frequently used tap closest to the source, but before any filtration system in the pipeline. The filter covering the tap is removed, the end of the tap is sanitized, and the water is allowed to run for 2 to 3 min before collecting the water sample. This type of sampling tests water from the origin and gives a better indication of water source quality. Therefore, point-of-use water sampling gives a good indication of the potential for milking equipment contamination and ultimately raw milk contamination that comes into contact with the wash water.

The study farms were concentrated around the southern perimeter of the map of southern Ontario along the Great Lakes. There is also a large contingent of study farms in the central portion of southwestern Ontario, containing farmland rich in nutrients. There was highly significant clustering identified in E. coli samples and coliform samples in water. The 3 clusters of $E$. coli contamination were all situated in close proximity to the Great Lakes. There are many possible explanations for the nature of these cluster occurrences and their specific locations such as the presence of wildlife, migratory birds, underlying rock formations, and drainage patterns. For example, the route of the water contamination could be from surface or ground water sources. If the water source is from surface water, contamination could be a result of wildlife or farm animals polluting the source. Alternatively, if the source is from ground water, there might be an underlying problem in the ground water system. A recent publication noted that many cities bordering the Great Lakes are dumping large amounts of sewage into the lakes and polluting the ecosystem (Sierra Legal, 2006). This pollution could play a role in the $E$. coli clusters that border the lakes. Monitoring programs need to be implemented in these cluster locations to help prevent raw milk contamination by means of wash water.

Gelsomino et al. (2002) performed a study to determine the source of $E$. coli contamination in unpasteur- ized cheese. It was found that the most likely source of contamination was the milking equipment. They found $E$. coli in the rinse water from the bulk tank and milking equipment, as well as in the tap water on the farm. Further investigations of the farm clusters identified in the present study with relation to watersheds, cattle density, human infections, or population density may be worthwhile to identify possible spatial relationships.

In the current study, it was hypothesized that the occurrence of bacteria such as E. coli and coliforms in wash water samples on dairy farms had the opportunity to result in elevated bacteria counts in raw bulk tank milk by way of bacteria remaining in milk lines between washings. This possible outcome would be harmful to

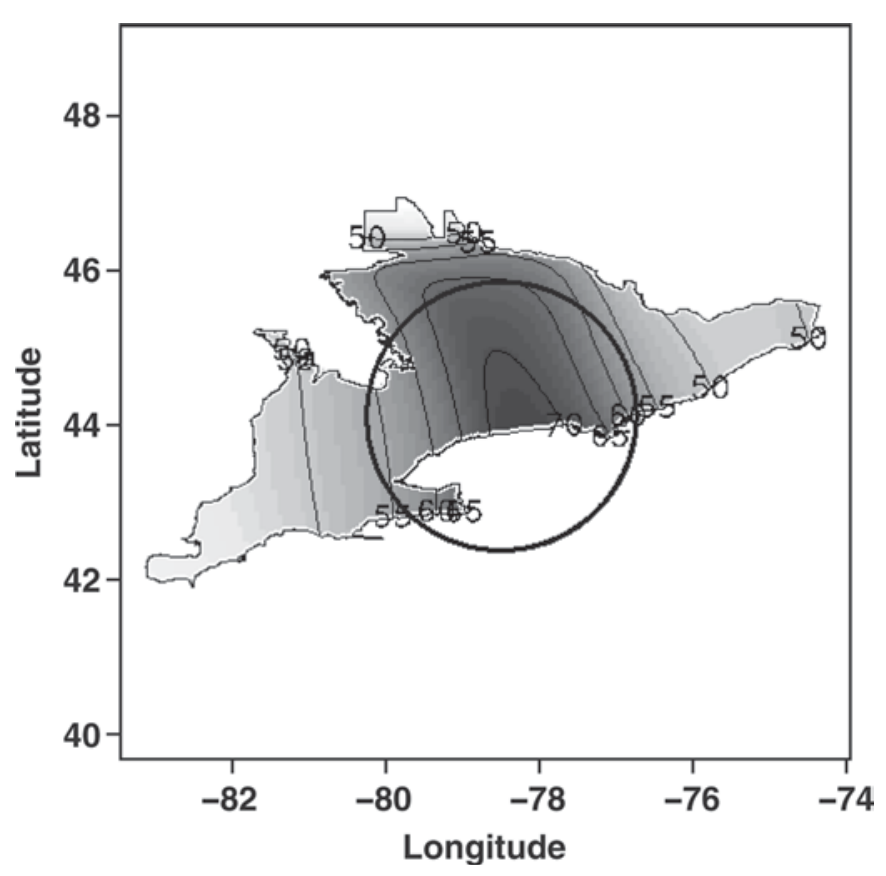

Figure 3. A risk map of coliform-contaminated water on dairy farms in southern Ontario, Canada, depicted using degrees (N) latitude and degrees (W) longitude with contour lines to identify the risk levels of water contamination. The coliform cluster comprised 2,132 farms, of which 1,414 were case farms. The coliform cluster was the largest cluster in the data and had a radius of $195 \mathrm{~km}$, located in the central portion of southern Ontario. 


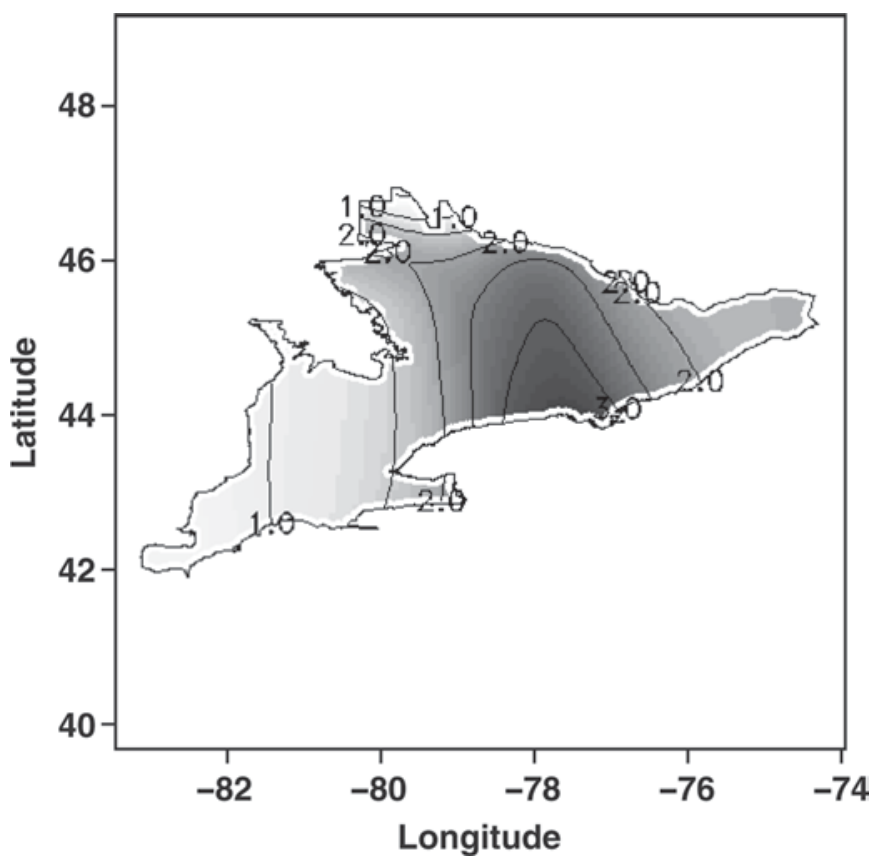

Figure 4. A relative risk map of elevated Escherichia coli levels in wash water on dairy farms in southern Ontario, Canada, depicted using degrees $(\mathrm{N})$ latitude and degrees $(\mathrm{W})$ longitude with contour lines to identify the corresponding relative risk levels of water contamination.

the quality of raw milk in Ontario. In situations of protocol breakdown, wash water of poor quality may significantly contribute to bacterial contamination of raw milk. Similarly, in situations of poor management, the effects of contaminated wash water will be more detrimental to the quality of raw milk in Ontario. The pasteurization process does not kill all of the bacteria within milk (Unc, 2004). Furthermore, many farm families still consume raw milk or raw milk products (Hegarty et al., 2002). Therefore, milking surfaces need to be cleaned with a potable water supply to ensure the production of a high-quality milk product that is safe for the consumer. This study found that the prevalence of $E$. coli in wash water was significantly associated with elevated milk bacteria counts in bulk tank milk. In addition, monthly SCC average interacting with monthly total milk produced by farm and interacting with season was significantly associated with elevated milk bacteria counts in bulk tank milk.

Our results showed that the presence of E. coli in the water on the dairy farm was related to an increase in milk bacteria counts in raw milk. Studies have shown that $E$. coli isolated in raw milk in turn creates a spike in microbial counts of raw milk (Hayes et al., 2001). The bacterial content of raw bulk tank milk can originate from several sources such as from inside the udder, the exterior of the udder and teats, or the milk- ing and storage equipment (Bramley and McKinnon, 1990). Coliforms such as E. coli are found throughout the farm environment. They can cause mastitis in the cows and can be shed from the udder into the milk. Moreover, E. coli can be found in bedding and fecal matter on farms and have been linked to milking and storage equipment that was improperly cleaned. The presence of $E$. coli in the water on the dairy farm indicates that contamination has occurred and that this contamination is potentially the reason for elevated bacteria counts in raw bulk tank milk (Hayes et al., 2001). Escherichia coli have been found to have a large effect on bacteria counts in milk, more so than other bacteria types. Hayes et al. (2001) found that when $E$. coli were isolated in raw milk, the average resulting increase in total bacteria count was $375,000 \mathrm{cfu} / \mathrm{mL}$, compared with $82,000 \mathrm{cfu} / \mathrm{mL}$ for other bacteria types. In general, E. coli prevalence in bulk tank milk is quite low (Steele et al., 1997; Jayarao and Wang, 1999). However, E. coli contamination has been linked to several outbreaks of human disease linked to dairy products (Zhao et al., 1995; Allerberger et al., 2001). Escherichia coli is a very hardy organism and has a low infectious dose for humans, making it an important food safety risk (Oliver et al., 2005). Therefore, it is important to routinely monitor water quality and prevent possible contamination of raw milk on dairy farms.

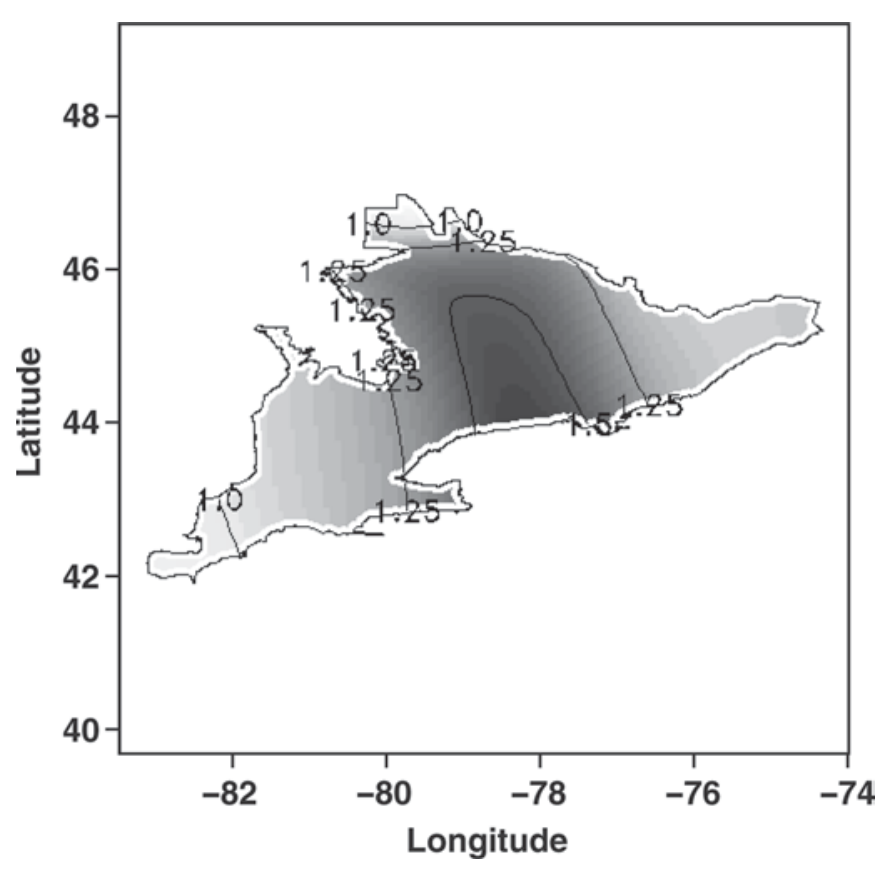

Figure 5. A relative risk map of elevated coliform levels in wash water on dairy farms in southern Ontario, Canada, depicted using degrees $(\mathrm{N})$ latitude and degrees $(\mathrm{W})$ longitude with contour lines to identify the corresponding relative risk levels of water contamination. 
Table 3. Final linear regression model for milk bacteria counts in raw bulk tank milk from dairy farms in Ontario

\begin{tabular}{|c|c|c|c|}
\hline Predictor & Coefficient & $\mathrm{SE}$ & $P$-value \\
\hline Intercept & 11.251 & 0.04 & $<0.0001$ \\
\hline Cool months & 1.129 & 0.04 & 0.0010 \\
\hline Warm months & Referent & & \\
\hline Total milk ${ }^{1}$ & -1.024 & 0.01 & $<0.0001$ \\
\hline $\mathrm{SCC}_{\text {average }}^{2}$ & 1.019 & 0.00 & $<0.0001$ \\
\hline Total milk $\times$ SCC average & 1.000 & 0.00 & $<0.0001$ \\
\hline SCC average $\times$ cool months & 1.000 & 0.00 & 0.0152 \\
\hline SCC average $\times$ warm months & Referent & & \\
\hline Escherichia coli $0^{3}$ & -1.057 & 0.02 & 0.0099 \\
\hline E. $\operatorname{coli} 1^{4}$ & Referent & & \\
\hline
\end{tabular}

The current study found that season of the year, either warm (May-September) or cool (October-April), in conjunction with the average monthly SCC, had a significant effect on milk bacteria counts. The results suggested that bacteria counts in raw milk were higher in the cooler months compared with the warmer months. Elevated SCC is an indicator of subclinical mastitis in dairy cows. It has been suggested that a higher proportion of the total bacteria in raw bulk tank milk in the winter originate from the cow as opposed to the milking equipment (McKinnon et al., 1990). In addition, farms that are managed in a grazing practice (cattle are allowed to graze outside between May and October) have lower bacteria counts in bulk tank milk samples from May to October than herds that keep animals confined for that period (Goldberg et al., 1992). A large proportion of the herds within Ontario are housed in tie-stall facilities that allow a daily exercise period in an exercise yard or on pasture (Zurbrigg et al., 2005), more often during the summer months (Sargeant et al., 1997). The practice of grazing cattle in the warm months, in addition to a higher proportion of bacteria originating from cows in the winter, may account for the effect of season and monthly SCC average on milk bacteria counts. Therefore, in the cooler months, more bacteria are found within the bulk tank because of an increase in bacteria from the cow directly.

Regardless of monthly total on-farm milk production collected in this study as monthly SCC average increases, there were resulting increases in milk bacteria counts. Total monthly milk production on-farm was used in this analysis as a surrogate measure of farm size. At higher levels of monthly bulk tank SCC averages $(>300,000$ cells $/ \mathrm{mL})$, the increase in milk bacteria counts as total monthly milk production increased was more pronounced than at lower levels of monthly SCC averages. Alternatively, at low monthly SCC averages
$(<300,000$ cells $/ \mathrm{mL})$, there was a slight decrease in milk bacteria counts as total milk produced by herd increased, possibly as a result of dilution. Good management practices and the style of management of the producer are indicators of high or low bulk milk SCC on the farm (Barkema et al., 1999). Therefore, lower farm management ability, through the monthly SCC average, may explain the increase in milk bacteria counts. The total monthly milk production within farm or the size of the farm does not tend to fluctuate considerably throughout the year or even over several years. However, the monthly SCC averages have a known seasonal pattern (Schukken et al., 1992), as well as the opportunity to increase and decrease depending on several factors (Schukken et al., 1993). It is important to acknowledge that, regardless of milk production (farm size), the increase in milk bacteria counts as monthly SCC average increased was quite substantial. Therefore, increases in SCC because of poor management practices can have a detrimental effect on the quality of bulk tank raw milk in Ontario.

\section{CONCLUSIONS}

From the current study, we concluded that the quality of the wash water used to clean the milking equipment had a small but significant effect on the quality of the raw milk produced. If a farm is on the verge of a penalty violation, the small effect of wash water quality on milk bacteria counts may push that producer into penalty range. Further research should focus on the distribution of E. coli and coliform cases in cattle, humans, and milk in conjunction with water contamination to determine if contaminated water is the route of transmission of $E$. coli infection to cows, to humans, or from raw milk contamination. In conclusion, the quality of wash water on Ontario dairy farms does not have a large effect on raw 
milk quality. However, in situations of protocol breakdown, wash water of poor quality may significantly contribute to bacterial contamination of raw milk. Milking surfaces need to be cleaned with a potable water supply to ensure the production of a high-quality milk product that is safe for the consumer.

\section{REFERENCES}

Aamodt, G., S. Samuelsen, and A. Skrondal. 2006. A simulation study of three methods for detecting disease clusters. Int. J. Health Geogr. 5:15-26.

Allerberger, F., M. Wagner, P. Schweiger, H. Rammer, A. Resch, M. P. Dierich, A. W. Friedrich, and H. Karch. 2001. Escherichia coli O157 infections and unpasteurized milk. Euro Surveill. 6:147-151.

Barkema, H. W., J. D. Van der Ploeg, Y. H. Schukken, T. J. G. M. Lam, G. Benedictus, and A. Brand. 1999. Management style and its association with bulk milk somatic cell count and incidence rate of clinical mastitis. J. Dairy Sci. 82:1655-1663.

Berke, O. 2005. Exploratory spatial relative risk mapping. Prev. Vet. Med. 71:173-182.

Bramley, A. J., and C. H. McKinnon. 1990. The microbiology of raw milk. Pages 163-208 in Dairy Microbiology. Vol. 1. The Microbiology of Milk. 2nd ed. R. K. Robinson, ed. Elsevier Science Publishers, London, UK.

Cuzick, J., and R. Edwards. 1990. Spatial clustering for inhomogeneous populations. J. R. Stat. Soc. Ser. B. Methodol. 52:73-104.

Dairy Farmers of Ontario. 2004. DFO Policies. 24th ed. Dairy Farmers of Ontario, Mississauga, ON.

Dairy Farmers of Ontario. 2006. General Manager's Report.480:1-14.

Gelsomino, R., M. Vancanneyt, T. M. Cogan, S. Condon, and J. Swings. 2002. Source of enterococci in a farmhouse raw-milk cheese. Appl. Environ. Microbiol. 68:3560-3565.

Goldberg, J. J., E. E. Wildman, J. W. Pankey, J. R. Kunkel, D. B. Howard, and B. M. Murphy. 1992. The influence of intensively managed rotational grazing, traditional continuous grazing, and confinement housing on bulk tank milk quality and udder health. J. Dairy Sci. 75:96-104.

Goss, M. J., D. A. J. Barry, and D. L. Rudolph. 1998. Contamination in Ontario farmstead domestic wells and its association with agriculture: 1. Results from drinking water wells. J. Contam. Hydrol. 32:267-293.

Hayes, M. C., R. D. Ralyea, S. C. Murphy, N. R. Carey, J. M. Scarlett, and K. J. Boor. 2001. Identification and characterization of elevated microbial counts in bulk tank raw milk. J. Dairy Sci. 84:292-298.

Hegarty, H., M. B. O'Sullivan, J. Buckley, and C. Foley-Nolan. 2002. Continued raw milk consumption on farms: Why? Commun. Dis. Public Health 5:151-156.

Holm, C., T. Mathiasen, and L. Jespersen. 2004. A flow cytometric technique for quantification and differentiation of bacteria in bulk tank milk. J. Appl. Microbiol. 97:935-941.

Jayarao, B. M., and L. Wang. 1999. A study on the prevalence of gramnegative bacteria in bulk tank milk. J. Dairy Sci. 82:2620-2624.
Kuldorff, M. 2006. SatScan.5.1.1. Boston, MA. http://www.satscan. org/.

Kulldorff, M., and N. Nagarwalla. 1995. Spatial disease clusters: Detection and inference. Stat. Med. 14:799-810.

Lopes, A. C., and T. L. Stamford. 1997. Critical control points in the pasteurized milk processing fluxogram. Arch. Latinoam. Nutr. $47: 367-371$

McKinnon, C. H., G. J. Rowlands, and A. J. Bramley. 1990. The effect of udder preparation before milking and contamination from the milking plant on bacterial numbers in bulk milk of eight dairy herds. J. Dairy Res. 57:307-318.

Michel, P., J. B. Wilson, S. W. Martin, R. C. Clarke, S. A. McEwen, and C. L. Gyles. 1999. Temporal and geographical distributions of reported cases of Escherichia coli O157:H7 infection in Ontario. Epidemiol. Infect. 122:193-200.

Oliver, S. P., B. M. Jayarao, and R. A. Almeida. 2005. Foodborne pathogens in milk and the dairy farm environment: Food safety and public health implications. Foodborne Pathog. Dis. 2:115129.

Saran, A. 1995. Disinfection in the dairy parlour. Rev. Sci. Tech. 14:207-224.

Sargeant, J. M., D. F. Kelton, S. W. Martin, and E. D. Mann. 1997. Associations between farm management practices, productivity, and bovine leukemia virus infection in Ontario dairy herds. Prev. Vet. Med. 31:211-221.

Schukken, Y. H., K. E. Leslie, A. J. Weersink, and S. W. Martin. 1992. Ontario bulk milk somatic cell count reduction program. 1. Impact on somatic cell counts and milk quality. J. Dairy Sci. 75:3352-3358.

Schukken, Y. H., A. Weersink, K. E. Leslie, and S. W. Martin. 1993. Dynamics and regulation of bulk milk somatic cell counts. Can. J. Vet. Res. 57:131-135.

Sierra Legal. 2006. The Great Lakes Sewage Report Card. http:// www.ecojustice.ca/publications/reports/the-great-lakes-sewagereport-card/attachment Accessed Nov. 30, 2006.

Song, C., and M. Kulldorff. 2003. Power evaluation of disease clustering tests. Int. J. Health Geogr. 2:9.

Steele, M. L., W. B. McNab, C. Poppe, M. W. Griffiths, S. Chen, S. A. Degrandis, L. C. Fruhner, C. A. Larkin, J. A. Lynch, and J. A. Odumeru. 1997. Survey of Ontario bulk tank raw milk for foodborne pathogens. J. Food Prot. 60:1341-1346.

Unc, A. 2004. Water used to wash milk contact surfaces. 1st ed. Dairy Farmers of Ontario. University of Ottawa and University of Guelph, Ontario, Canada.

United States Environmental Protection Agency. 2002. Method 1604: Total coliforms and Escherichia coli in water by membrane filtration using a simultaneous detection technique (MI medium). EPA 821-R-02-024:1-14. Office of Water, US Environmental Protection Agency, Washington, DC.

Zhao, T., M. P. Doyle, J. Shere, and L. Garber. 1995. Prevalence of enterohemorrhagic Escherichia coli O157:H7 in a survey of dairy herds. Appl. Environ. Microbiol. 61:1290-1293.

Zurbrigg, K., D. Kelton, N. Anderson, and S. Millman. 2005. Stall dimensions and the prevalence of lameness, injury, and cleanliness on 317 tie-stall dairy farms in Ontario. Can. Vet. J. 46:902-909. 